\title{
Cull cow management and its implications for cow-calf profitability
}

\author{
RANDALL D. LITTLE, ALLEN R. WILLIAMS, R. CURT LACY, AND CHARLIE S. FORREST
}

Authors are Associate Professor, Department of Agricultural Economics, Associate Professor, Department of Animal and Dairy Sciences, Graduate Research Assistant and Extension Specialist, Department of Agricultural Economics, Mississippi State University, Mississippi State, Mississippi 39762. Dr. Little is the corresponding author. (662) 325-2884; fax: (662)325-8777; email: little@agecon.msstate.edu

\begin{abstract}
Selling culled breeding livestock is often viewed as "just another chore." Most cull sales are made in the fall, after calves are weaned and cows are pregnancy checked and open. Since cull cow sales comprise from 15 to $30 \%$ of a cow-calf enterprise's gross revenue, perhaps they should be viewed as a potential profit center.

This paper uses enterprise budgets and sensitivity analyses to illustrate cull cow management strategies that overcome certain physical and economic factors that limit the profitability of fall cow sales. The key limiting physical factor is often poor body condition, which results from the combined effect of lactation and deteriorating forage quality. The key economic factor is a seasonal price low, generated by a large beef supply in the fall.

The results suggest potential, with adequate, low-cost feedstuffs, to increase net returns by properly managing cull breeding stock. In only 1 year during the 10-year period, 1990-1999, was selling cull cows in the fall the more profitable option. Over that time period, the net present value of spring cull sales averaged about $\$ 30$ per cow more than selling cull cows in the fall.
\end{abstract}

Key Words: seasonal price trends, net present value

Selling culled breeding livestock is often viewed as "just another chore." Most sales are made in the fall, after calves are weaned and cows are pregnancy checked and found to be open. Since cull cow sales comprise from 15 to 30 percent of a cow-calf enterprise's gross revenue, the culling activity should, perhaps, be viewed and managed as a potential profit center.

The purpose of the research reported in this paper was to determine if cull cow management strategies using cool season forages on improved pastures can overcome certain physical and economic factors limiting the profitability of fall cull sales. The key physical factor that frequently limits the profit potential of fall sales is poor body condition. Cows typically start the fall season in poor body condition because of the combined effect of the demands of lactation and the deteriorating quality of summer forages. The key economic effect is a seasonal price low, generated by large fall supplies (Fuez 1996, Spreen and Simpson 1992). While the model used reflects a production situation typical throughout much of the Southeastern U.S., the theoretical frame-

Manuscript accepted 30 May 2001.
Resumen

La venta de ganado para crianza que es de baja produccion (o no productivo), es una actividad que normalmente es considerada como una "tarea rutinaria mas" en el manejo del ganado. La mayor parte de las ventas de este ganado se lleva a cabo durante la epoca de Primavera, despues que las crias han sido destetadas y las vacas han sido revisadas y comprobadas que estan libres de preñez. La venta de gando de baja producion abarca entre un 15 a 30 porciento del ingreso bruto de las operaciones de vaca para cria, por lo que esta actividad deberia ser vista como una potencial fuente de ganancia.

Esta publicacion hace uso de presupuesto de operaciones y analisis de sensibilidad para ilustrar estrategias en el manejo de ganado de baja producion, que ayudan a eliminar o reducir ciertos factores fisicos y economicos que limitan la alta rentabilidad en las ventas de ganado durante la Primavera. El principal factor fisico limitante, es a menudo una pobre condicion corporal del ganado, lo cual es el resultado del efecto combinado de pobre lactacion y la deteriorada calidad del forrage. El principal factor economico es un bajo precio temporal durante la epoca de Primavera, generado por una alta oferta de reses durante la epoca de Otoño.

Los resultados del analisis presentado indican un incremento potencial en el retorno neto, dado un manejo apropiado del ganado con una adecuada alimentacion, utilizando material alimenticio de bajo costo. Solamente en un año durante el periodo de 10 años (1990-1999), la opcion de mayor ganacia fue vender el ganado de baja producion durante el Otoño. Durante este mismo periodo el Valor Presente Neto (VPN) de las ventas de ganado de baja produccion durante la Primavera tuvo una ganacia promedio de $\$ \mathbf{3 0 . 0 0}$ mas alto por cabeza, comparadas con las ventas en Otoño.

work and methods are pertinent to any place quality cool season forages can be produced.

\section{Cull Cow Grades}

Cull cows are sold based on USDA slaughter grades, which can be related to body condition scores (BCS) (Table 1). The BCS is a system that uses visual appraisal to determine the degree of fat or muscle loss an animal exhibits. Body condition is scored from 1 to 9 , with 9 being the fattest classification. An evaluation of fat 
Table 1. Cull cow grades and characteristics.

\begin{tabular}{lccc}
\hline \hline Grade & Dressing Percent & Lean Content of Trimmings & Cow BCS \\
\hline Canner & $40-46$ & $90-92$ & $1-3$ \\
Cutter & $45-49$ & $88-90$ & $4-5$ \\
Utility & & & \\
Boning & $50-52$ & $78-83$ & $5-9$ \\
Breaking & $52-54$ & $76-82$ & $6-9$ \\
Commercial & $55-60$ & $70-80$ & $5-9$ \\
\hline
\end{tabular}

Source: Gill (1998).

deposits at various locations of the body (back, tail head, pins, hooks, ribs, and brisket) is made to estimate the potential carcass cutout quality. An animal with a score of 5 should look average without being too thin or too fat. Animals with a score of 3 or below will have little or no fat and are scored on the degree of muscle loss.

The USDA Utility and Commercial cows usually command the best prices and have the highest dressing percentage (50 to 60 percent). They typically have body condition scores of 5 or higher. Cows that grade USDA Utility or Commercial usually have enough intramuscular fat (marbling) and muscling for primals to be pulled from the carcass (particularly cuts from the rib and loin) and marketed outside of the ground meat trade. This greatly enhances the value of a carcass, which, in turn, generates premiums paid for the higher quality animals.

\section{Cow Prices - Historical and Trends}

Figure 1 illustrates the volatility slaughter cow prices exhibit over time. For the 19-year period shown, average monthly cow prices (in nominal dollars) ranged from a high of $\$ 1.26$ per $\mathrm{kg}$ to a low of about $\$ 0.64$ per kg. Also evident in Figure 1 is the cyclical nature of cattle prices.

Not only is price variability an important factor, but seasonal price trends (Boyles, Spreen and Simpson 1992, Torell et al. 1998) and the price differentials between grades of cull cows (Gill 1998) are also critical to effective cull cow management and marketing decisions. On average, the difference in price between USDA Utility and Cutter is about \$0.09 per kg (Fig. 2). Figure 2 also shows the seasonal price patterns inherent in slaughter cow prices. Prices normally peak in March and decline steadily through November. Torell et al. (1997) note that "flesh adds weight and that weight adds value" (p. 955-2). Thus, if possible, it may be advantageous to target marketing of cull cows in the early spring at a body condition score of 5-6 and avoid marketing in the fall, particularly if cows are in poor body condition.

\section{Materials and Methods}

It may be profitable for producers to take advantage of favorable seasonal price trends and the premiums for animals in better body condition. The analysis reported in this paper used a partial budgeting approach in which the cull cow selling activity was treated as an independent livestock enterprise. An enterprise budget for the cull or stocker cow activity was developed (Table 2). Interest is charged on the purchase of the stocker cow over the 6-month period; the other expense items

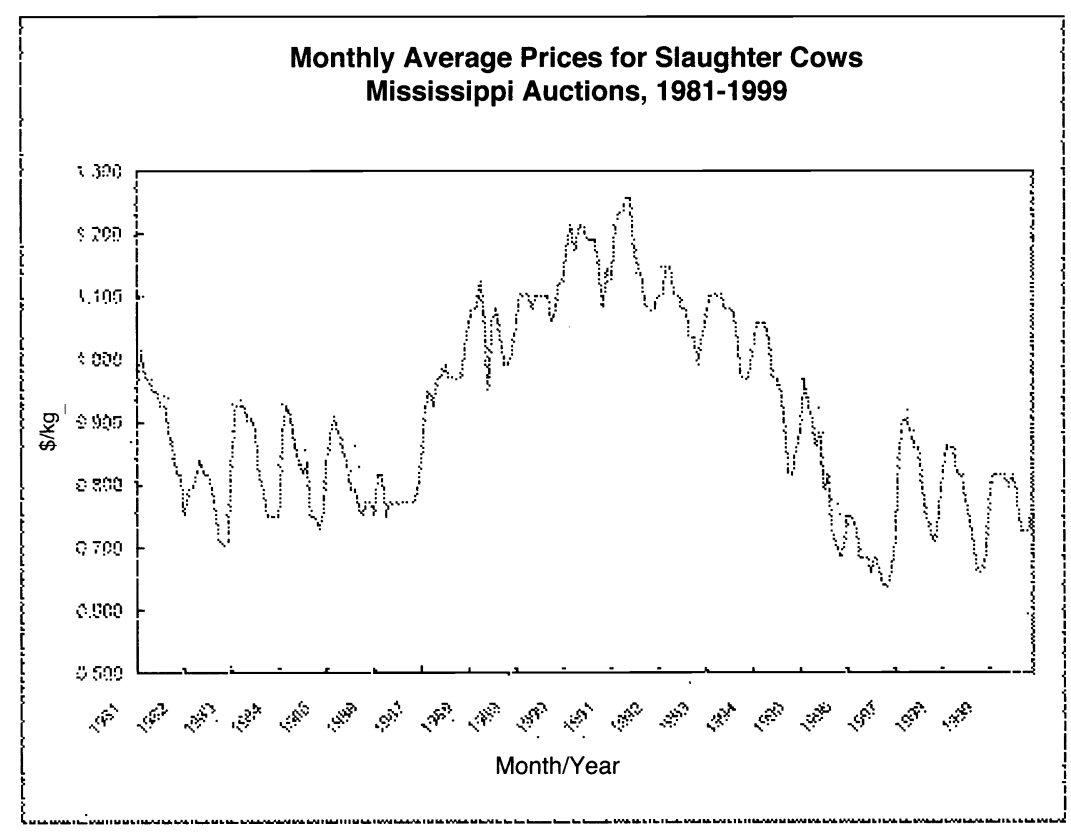

Fig. 1. Monthly Average Utility Cow Prices in Mississippi, 1981 to 1999.

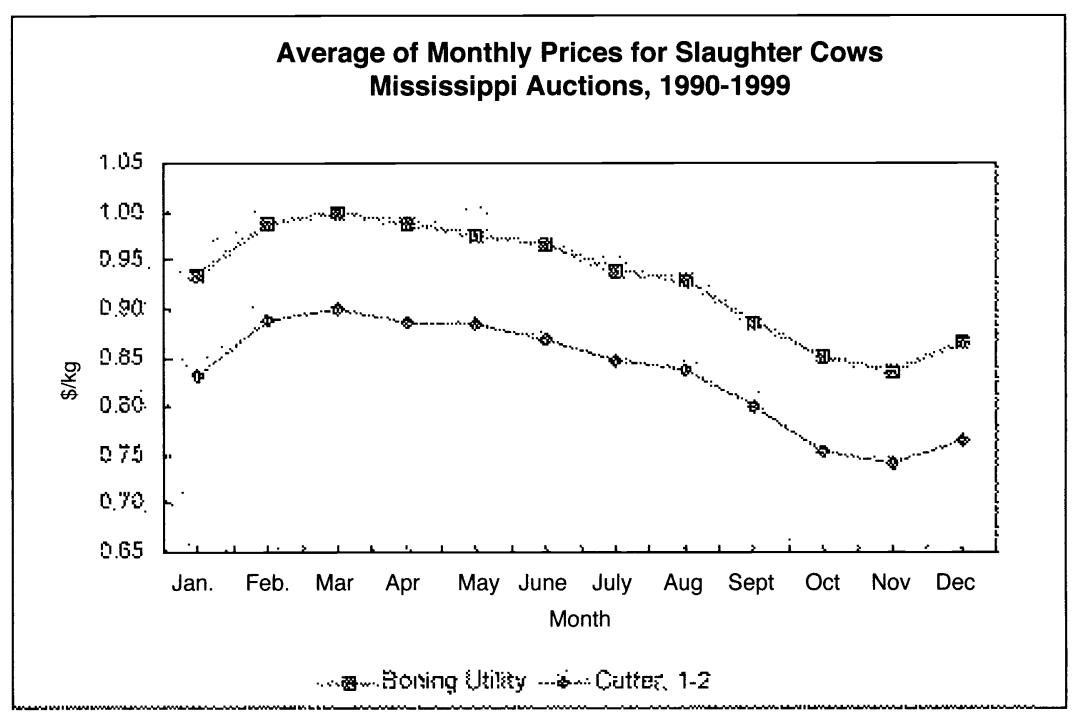

Fig. 2. Seasonal Price Patterns for Cull Cows in Mississippi, 1990 to 1999. 
Table 2. Estimated Income and Expenses for Overwintering Cull Cows in Mississippi.

\begin{tabular}{llrrr}
\hline \hline Item & Unit & Price & Quantity & \multicolumn{1}{c}{ Amount } \\
\hline INCOME & & (dollars) & & (dollars/cow) \\
Cull cows (Utility) 80\% & $\mathrm{Kg}$ & 1.12 & $(499.0 * 80 \%)$ & 446.69 \\
Cull cows (Cutter) 20\% & $\mathrm{Kg}$ & 1.01 & $(453.6 * 20 \%)$ & 91.26 \\
Total Income & & & 537.95 & \\
Total Income Per Kg Sold & & & 1.10 & \\
DIRECT EXPENSES & $\mathrm{Kg}$ & 0.86 & 362.9 & 311.76 \\
Canner/Cutter & $\%$ & 0.01 & 312 & 3.12 \\
Death Loss & $\mathrm{Ha}$ & 49.42 & 0.607 & 30.00 \\
Pasture Rental (fescue) & $\mathrm{Kg}$ & 0.2425 & 81.65 & 19.80 \\
Protein Supplement & $\mathrm{Kg}$ & 0.0782 & 508 & 39.72 \\
Hay & $\mathrm{Head}$ & 4.00 & 1.00 & 4.00 \\
Salt/minerals & $\mathrm{Hrs}$ & 6.50 & 1.50 & 9.75 \\
Labor & $\mathrm{Head}$ & 5.00 & 1 & 5.00 \\
Veterinary/health mgt. & $\mathrm{Head}$ & 2.50 & 1 & 2.50 \\
Mach., fuel, oil & $\mathrm{Head}$ & 10.00 & 1 & 10.00 \\
Marketing & $\mathrm{Head}$ & 5.00 & 1 & 5.00 \\
Supplies \& misc. & Dol. & 0.090 & 376.21 & 16.70 \\
Interest (for 6 months) & & & 457.35 \\
Total Direct Expenses & & & & \\
Breakeven Selling Price & & & & 0.934 \\
(weighted average, \$/Kg) & & & & 0.65 \\
Returns above Direct Expenses & & & & \\
Net Returns per Kg sold & & & & \\
\hline
\end{tabular}

are assumed to be distributed equally over the period.

The budget presented in Table 2 was based on the assumption that cows will graze fescue from 1 November to 1 May. Cows were assumed to enter the program at $363 \mathrm{~kg}$ (at a body condition score of 4 or less), grading USDA Cutter or Canner. It is recognized that not all culled cows will grade so poorly, clearly there are other reasons besides poor body condition why some cows are open, but this is a major criterion in the culling decision.

An average daily gain of $0.757 \mathrm{~kg}$ over the 180 day feeding period was assumed. It is estimated that most cows gaining at this rate will grade USDA Utility (body condition score of 5-6) by early spring. Research has shown that about $80 \%$ of animals should reach this desired body condition (Schnell et al. 1997, Rasby et al. 2000); hence it was assumed that 80 percent of the cull cows grade Utility and the remainder grade Cutter. Cows that grade Utility were assumed to weigh $499 \mathrm{~kg}$ at the time of sale, while the cows grading Cutter were assumed to weigh $454 \mathrm{~kg}$.

Real prices $(1999=100)$ were used to eliminate the effect of inflation on prices received, so prices across years would be more directly comparable. The consumer price index was used as the deflator. The average Utility and Cutter prices (in real dollars) received for the sale of cull cows in the spring were $\$ 1.12$ and $\$ 1.01$ per $\mathrm{kg}$, respectively. The producer was assumed to pay about $\$ 0.86$ per $\mathrm{kg}$ for Cutter grade cull cows in the fall or to value the ranch- build in an additional risk premium for extending ownership of the culled cows. A lower discount rate would slightly increase the present value of the returns from selling cull cows in the spring.

The NPV analysis includes as gross income the returns from selling $80 \%$ Utility grade and $20 \%$ Cutter grade cows in April. Average real April prices were used. All estimated expense items from the budget in Table 2 were included except the cost of cow purchase, since this reflects an attempt to portray a cow-calf producer's decision to retain ownership of cull cows, as compared to a stocker cow enterprise. Instead, an opportunity cost of holding cows was included, based on income foregone had the returns from the fall cull sale been invested at $6 \%$. Net returns from the sale of culls in the fall and the corresponding NPV of the net returns from the sale of those cows the following spring were calculated using price data from the fall of 1989 to the spring of 1999 .

\section{Results}

To facilitate comparison of fall and spring cull sales within a cow-calf operation, the net present value (NPV) of the returns for sale in the spring was calculated. Net present value is an investment analysis technique that takes into account the time value of money and the timing of cash flows (Robison and Barry 1996).

Returns were discounted for the 180 days assumed in the cull cow enterprise using a $10 \%$ annual discount rate. While a discount rate between 6 and $9 \%$ is recommended (AAEA Task Force on Commodity Costs and Returns 1998), ten percent was used to

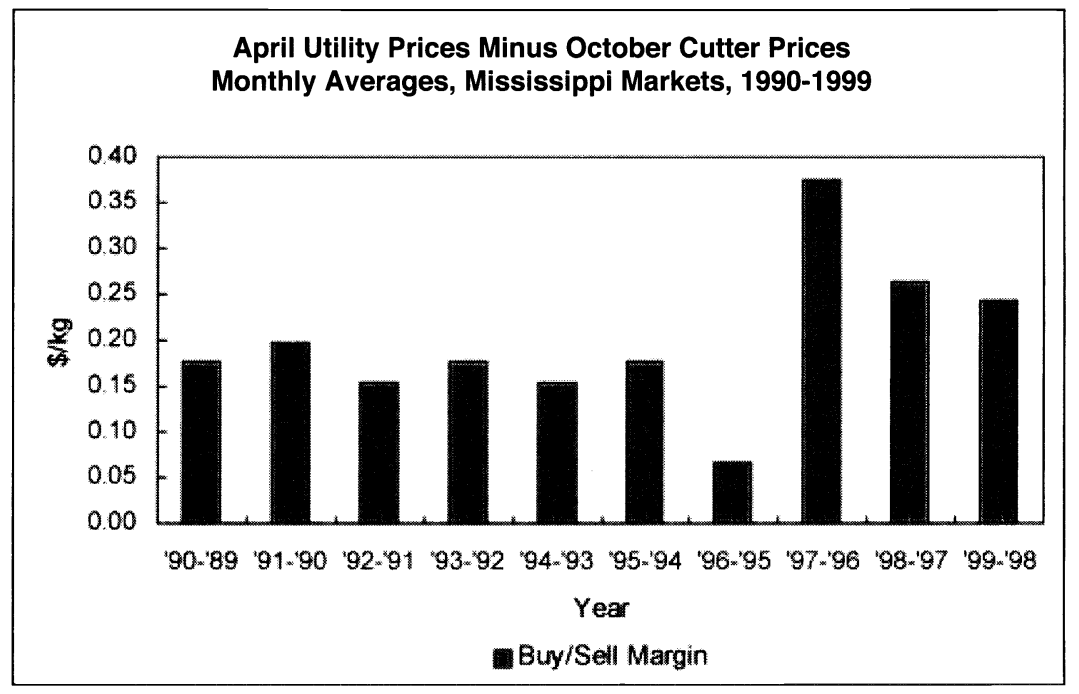

Fig. 3. Buy/Sell Margins for Cull Cows in Mississippi, 1990 to 1999. 
Table 3. Estimated Returns above Specified Expenses (dollars per cow) for Different Purchase and Selling Prices.

\begin{tabular}{lrrrrr}
\hline \hline PurchasePrice & \multicolumn{5}{c}{ Selling Price $(\$ / \mathrm{Kg})$} \\
\cline { 2 - 6 } & $\$ 0.79$ & $\$ 0.83$ & $\$ 0.88$ & $\$ 0.93$ & $\$ 0.97$ \\
\hline $\mathbf{\$} / \mathrm{Kg})$ & & & $(\$ /$ Cow $)$ & & \\
$\$ 0.79$ & -43.69 & -22.09 & -0.49 & 21.11 & 42.71 \\
$\$ 0.75$ & -26.81 & -5.21 & 16.39 & 37.99 & 59.59 \\
$\$ 0.74$ & -9.93 & 11.67 & 33.27 & 54.87 & 76.47 \\
$\$ 0.66$ & 6.95 & 28.55 & 50.15 & 71.75 & 93.35 \\
$\$ 0.62$ & 23.83 & 45.43 & 67.03 & 88.63 & 110.23 \\
$\$ 0.57$ & 40.71 & 62.31 & 83.91 & 105.51 & 127.11 \\
$\$ 0.53$ & 57.59 & 79.19 & 100.79 & 122.39 & 143.99 \\
\hline
\end{tabular}

Table 4. Estimated Returns above Specified Expenses (dollars per cow) for Different Total Feed Costs (dollars per cow) and Selling Prices.

\begin{tabular}{llcccc}
\hline \hline Total Feed Costs & \multicolumn{5}{c}{ Selling Price $(\$ / \mathrm{Kg})$} \\
\cline { 2 - 6 } & $\$ 0.79$ & $\$ 0.83$ & $\$ 0.88$ & $\$ 0.93$ & $\$ 0.97$ \\
\hline \multirow{2}{*}{$\$ 60.00$} & -38.38 & -16.78 & $(\$ /$ Cow $)$ & \\
$\$ 70.00$ & -48.60 & -27.00 & -5.40 & 26.42 & 48.02 \\
$\$ 80.00$ & -58.82 & -37.22 & -15.62 & 16.20 & 37.80 \\
$\$ 90.00$ & -69.04 & -47.44 & -25.84 & -4.24 & 27.58 \\
$\$ 100.00$ & -79.27 & -57.67 & -36.07 & -14.47 & 17.36 \\
$\$ 110.00$ & -89.49 & -67.89 & -46.29 & -24.69 & -13 \\
\hline
\end{tabular}

margin, which was calculated by subtracting the October Cutter cow price from the April Utility cow price of the next year, averaged about $\$ 0.20$ per $\mathrm{kg}$ over the 10 year period, 1990-1999. The range for this margin was from $\$ 0.07$ to $\$ 0.38$ per $\mathrm{kg}$. Although positive, the margins exhibit variability.

Table 3 presents the returns per cow, assuming different purchase and selling prices. Changes in weight gain and body condition are reflected in the price differentials of Table 3 , as those are key determinants of the price received in the spring. The importance of adequate margins between the fall purchase price and the spring selling price is highlighted in Table 3 , as returns above direct expenses per cow do not become positive until the difference between the fall and spring prices exceed $\$ 0.08$ per $\mathrm{kg}$.

The sensitivity of returns per cow to changes in feed costs is presented in Table 4. Total feed costs, including pasture costs, as reflected in the budget in Table 2, were about $\$ 90$ per cow. The returns in Table 4 assume the cull cows are purchased at the 10-year average price for cutter/canner in the fall. These results illustrate the importance of low-cost feedstuffs, in addition to the adequate price differentials from fall to spring discussed previously, to a profitable stocker cow enterprise.
The net present value of spring cull sales exceeded returns from fall sales in all but one (1995) of the 10 years studied (Fig. 4). This year was when the differential between fall and spring prices was least, $\$ 3.00$ between the fall of 1995 and spring 1996, and the only time during the study period when selling in the fall would have been more profitable. The difference between the NPV of the returns above direct expenses from spring cull sales and the sale of culls in the fall is illustrated in Figure 5. The average difference over the 10 -year period was about $\$ 30$ per cow. As in Table 3, the importance of an adequate price differential between the fall and spring prices to the profitability of holding cows for sale in the spring is highlighted.

\section{Discussion and Conclusions}

The objective of this paper was to determine if cull cow management strategies can overcome certain physical and economic factors limiting the profitability of fall cull sales. The key physical factor is often poor body condition, the combined effect of lactation and deteriorating summer forage quality. The key economic effect is a seasonal price low in the fall, due to the increase in quantity supplied in those months.

The results suggest that there is considerable and relatively stable opportunity to boost returns from the sale of cull cows by improving body condition with a costeffective feeding program and selling them in the spring. In only 1 year during the 10 -year study period was selling cull cows in the fall the more profitable option. Over that time period, the net present value of spring cull sales averaged about

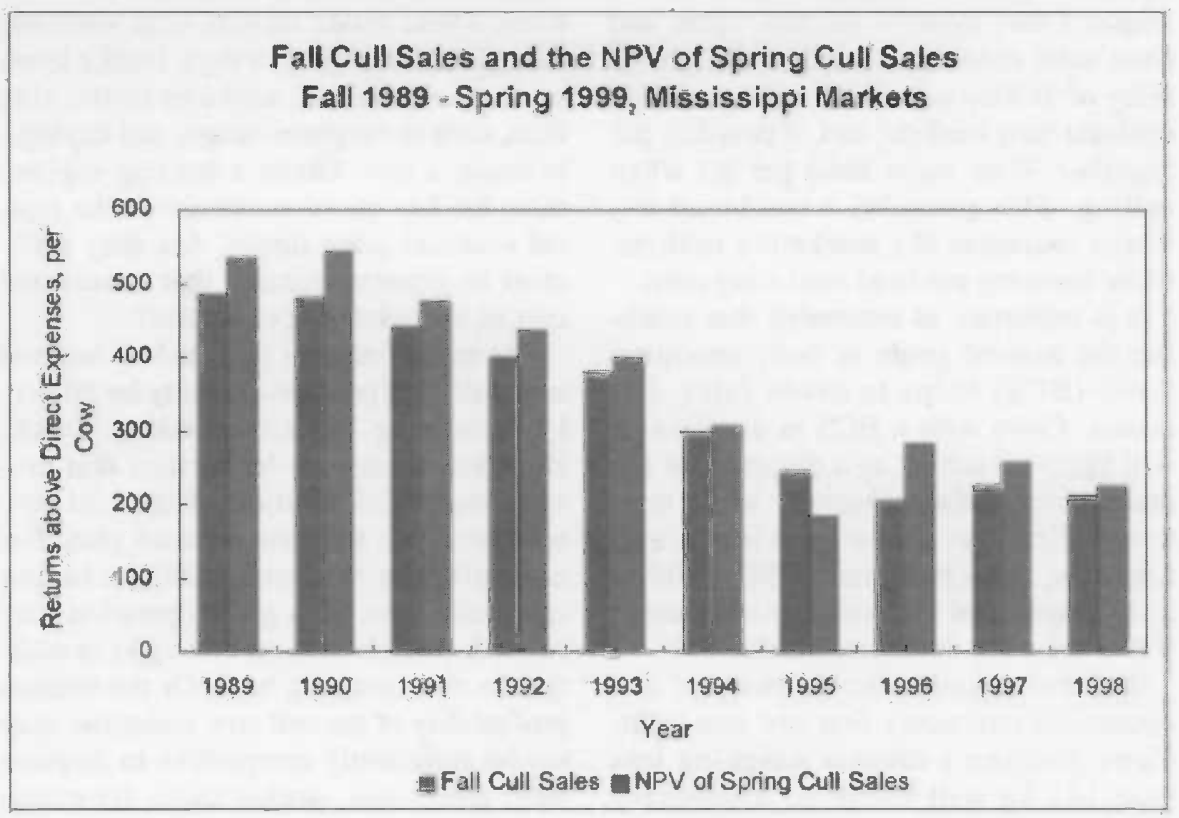

Fig. 4. Fall Cull Sales and the Net Present Value of Spring Cull Sales, 1989 to 1999. 


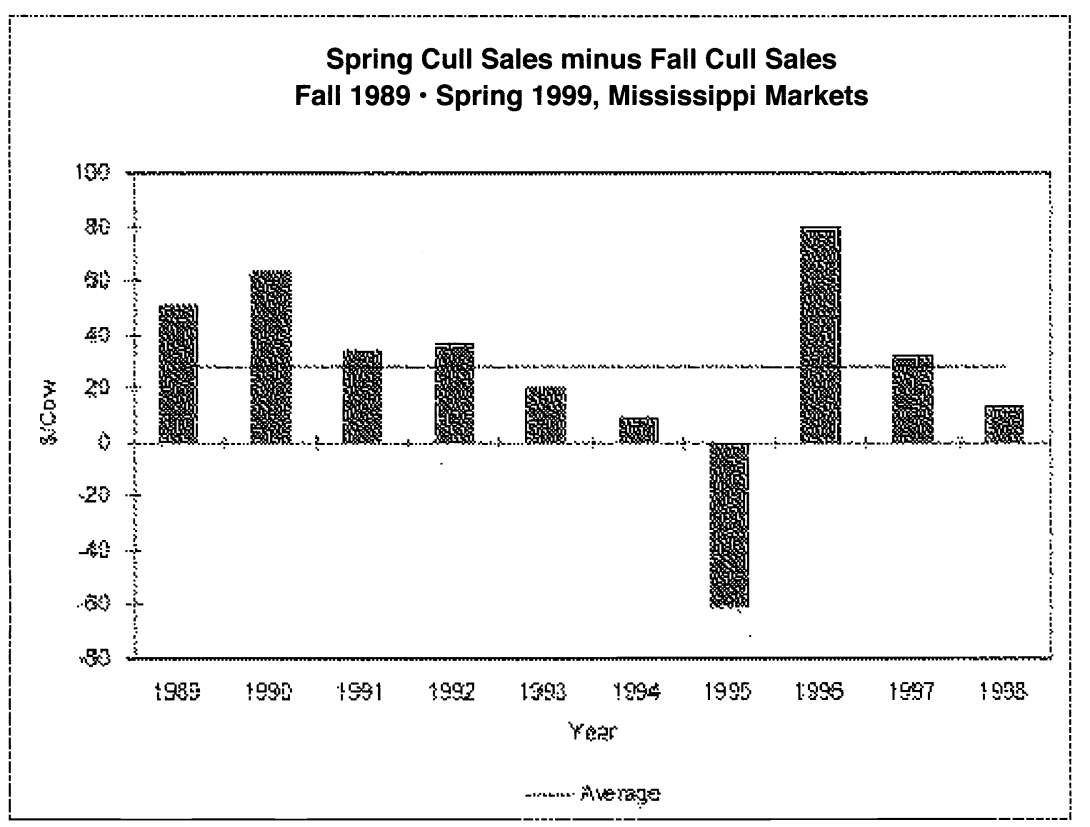

Fig. 5. Difference between the Net Present Value of Spring Cull Sales and Fall Cull Sales, 1989 to 1999.

$\$ 30$ per cow more than selling cull cows in the fall. Availability of low-cost feedstuffs, whether cool season forages or some other feed, is critical to the success of a cull cow enterprise.

There are several factors to consider when deciding to hold cull cows over for sale in the spring. Producers should estimate the weight and grade of their cull cows or purchased stocker cows. Cows should have the potential to gain 90 to 135 $\mathrm{kg}$ on forages and supplement over the winter. Cows must be healthy, open, and have solid mouths to increase the probability of making a profit. Producers should evaluate their markets, and, if possible, put together 40 or more head per lot when selling. This provides a truckload lot, which increases the marketing options, while lowering per head marketing costs.

It is important to remember that reaching the desired grade or body condition score (BCS) helps to avoid price discounts. Cows with a BCS in excess of 6 will likely be subject to a discount for too much external fat, especially when marketed directly to the packing plant. Likewise, cows that grade USDA Utility and Commercial are typically discounted if they have too much external fat.

Producers should also be aware of discounts on carcasses that are too light. Cows yielding a carcass weighing less than $181 \mathrm{~kg}$ will likely be discounted $\$ 0.33$ per $\mathrm{kg}$ or more. Cows that grade USDA Canner are the most likely to

avoid such discounts is to not market cows with a BCS of 4 or less. cost of overwintering cull cows? should consider how the cull cow enterprise fits into the whole farm or ranch plan before deciding to feed cull cows through the winter.

\section{Literature Cited}

AAEA Task Force on Commodity Costs and Returns. 1998. Commodity Costs and Returns Estimation Handbook. Ames, Iowa: Amer. Agr. Econ. Assoc.

Boyles, S. Undated. Feeding Cull Cows. Ohio State Univ. Ext.n Serv. http://www2.ag.ohiostate.edu/ beef/library/cull.html (Date of last access: 15 May, 2001)

Gill, R. 1998. Marketing Cull Cows Understanding What Determines Value. http://agnews.tamu.edu/drought/drght= pak98/drght11.html (Date of last access: 15 May, 2001)

Fuez, D.M. 1996. Feeding and Marketing Cull Cows. Research Report 96-2. Managing for Today's Cattle Market and Beyond. South Dakota State Univ.

http://ag.arizona.edu/AREC/WEMC/Todays CattlePub.html (Date of last access: 15 May, 2001)

Rasby, R., R. Selley, and T. Klopfenstein. 2000. Grazing Crop Residue. Nebraska Coop. Ext. EC 98-278-B.

The research reported here assumed the primary feed source was cool season forages on improved pasture, which implies a temperate winter climate. Consequently, the expenses shown in Table 2 reflect a grazing operation. A cull cow management program, however, can be effective with hay and/or cheap alternative feeds available in some years and at some locations. These could include crop residues, corn gluten feed (wet or dry), broiler litter, whole cottonseed, soybean hulls, rice bran, corn or sorghum silage, and haylage, to name a few. Given a feeding regime, then, the key question centers on the typical seasonal price trends. Are they sufficient to generate returns that exceed the

The results suggest potential to increase cow-calf enterprise profitability by properly managing culled breeding stock. However, there may be barriers that prevent successful addition of the cull cow enterprise into the farm or ranch plan. For example, the resource base, including space and time, on a given operation may be inadequate to support cull cows in addition to the remaining herd. Or the relative profitability of the cull cow enterprise may not be sufficiently competitive to displace other enterprises, stocker cattle, for example, for use of the operation's limited resources. Thus, individual managers
Robison, L.J. and P.J. Barry. 1996. Present Value Models and Investment Analysis. Northport, Ala: The Academic Page.

Schnell, T.D., K.E. Belk, J.D. Tatum, R.K. Miller, and G.C. Smith. 1997. Performance, Carcass, and Palatability Traits for Cull Cows Fed High Energy Diets for 0, 14, 28, 42, or 56 Days. J. Anim. Sci. 75:1195-1202.

Spreen, T.H. and J. Simpson. 1992. Seasonality of Cow Prices. $41^{\text {st }}$ Annual Florida Beef Cattle Short Course Proc.. Dept. of Ani. Sci., Univ. of Florida, Gainesville, Fla.

http://gnv.ifas.ufl.edu/ animal/short92/SPRE EN.HTM (Date of last access: 15 May, 2001)

Torell, R., B. Bruce, and G. Myer. 1997. What is a Cow Worth? Nevada Cattlemen's Assoc. Spec. Publ. 97-1:CL955-1.

Torell, R., B. Bruce, B. Kvasnicka, and T. Ringkob. 1998. Marketing Alternatives of "B" Maturity Cattle. Univ. of Nevada Coop. Exten. Fact Sheet 98-17. 